\title{
KAJIAN MUSIKAL KESENIAN WAROK DI DESA TALUNOMBO, KECAMATAN SAPURAN KABUPATENWONOSOBO
}

\author{
Tri Jeniati \\ Alumni Jurusan Karawitan Fakultas Seni Pertunjukan \\ Institut Seni Indonesia (ISI) Surakarta \\ Suyoto \\ Dosen Jurusan Karawitan Fakultas Seni Pertunjukan \\ Institut Seni Indonesia (ISI) Surakarta \\ Email: suyotoskar@gmail.com
}

\begin{abstract}
Abstrak
"Kajian Musikal Kesenian Warok di Desa Talunombo, Kecamatan Sapuran, Kabupaten Wonosobo" dilatarbelakangi bahwa kesenian warok memiliki beberapa ragam bentuk gending dan irama. Permasalahan musikal di dalamnya cukup kompleks, mulai dari instrumentasi, pola-pola garap permainan instrumen. Berbagai permasalahan musikal kesenian warok cukup menarik untuk diungkap, karena memiliki berbagai permasalahan musikal yang cukup kompleks. Persoalannya adalah 1) Bagaimana peran musik di dalam Kesenian Warok di Desa Talunombo Kecamatan Sapuran Kabupaten Wonosobo? 2) Bagaimana garap instrumen Kesenian Warok di Desa Talunombo Kecamatan Sapuran Kabupaten Wonosobo? Persoalan dimaksud diungkap dengan menggunakan konsep garap Rahayu Supanggah, dan teori fungsi oleh RM. Soedarsono. Hasil penelitian ditemukan, secara turun-temurun digantikan oleh generasi berikutnya, sehingga masih tetap eksis sampai sekarang. Peran musik dalam kesenian Warok sangat dominan. Kesan dapat terbentuk tidak hanya dari kostum, tata rias, atau gerak saja, namun bunyi instrumen pun dapat menciptakan kesan dari sebuah pertunjukan. Bunyi dari pola tabuhan mempunyai kesan yang dapat memperkuat karakter warok. Proses $n$ dadi dipercaya berkaitan dengan polapola tabuhan yang mendukungnya. Musik menjadi media seseorang meningkatkan emosi, kemudian direspon oleh tubuh. Pola tabuhan yang ritmik, menimbulkan rasa untuk bergerak. Ketika musik dalam tempo cepat, dengan kondisi fisik penari yang lelah sangat mudah untuk dirasuki oleh makhluk gaib. Garap gending kesenian Warok dibagi dalam tiga bagian, yaitu bagian pertama garap gending untuk penari putri, bagian ke dua garap gending untuk penari putra, bagian ke tiga garap gending untuk penari putra dan putri.
\end{abstract}

Kata kunci: Gending, Garap, Warok.

\begin{abstract}
The research background of "Musical Study On Warok Arts In Talunombo Village, Sapuran District Wonosobo Regency" is that Warok art has various forms of musical tunes and rhythms. The problem on its musical aspect is quite complex, ranging from its instrumentation and its playing patterns (garap) on its instruments. Various musical problems in Warok arts is interesting to be reveal because it has complex musical problems. Issues of this research are: 1) what is the role of music in Warok Art in Talunombo Village, Sapuran District, Wonosobo Regency. 2) How is work of instrument (garap) in Warok Arts? The problem of this research revealed using the concept of works of Rahayu Supanggah, and function theory by RM. Soedarsono. The results of the study found that the Warok arts is as existing legacy from generations. The role of music in Warok is very dominant. Impressions from Warok obtained not only by it costumes, make-up, or movement, but rather to the sound of the musical instruments that could create the impression of a performance. The sound of the wasp pattern has an impression that can strengthen the Warok character. The trance process believed having relation to the
\end{abstract}


wasp patterns that support it. Music becomes a media for a person to increase their emotions and to their body responds. Rhythmic wasp pattern causes a sense to a body movement. When the music played in fast tempo, the tired physical dancers could easily possessed by supernatural beings. Warok art works genre divided into three parts namely: 1.) works (garap) on music for female dancers, 2.) works (garap) on music for male dancers, and 3.) works (garap) on music for both male and female dancers.

Keywords: Gending, Garap, Warok.

\section{Pengantar}

Kesenian Warok adalah salah satu dari sekian jenis kesenian rakyat yang ada di wilayah Kabupaten Wonosobo, khususnya di Desa Talunombo Kecamatan Sapuran. Selain Warok di Talunombo terdapat beberapa kesenian lain seperti, Kuda Lumping, Dayakan, Rebana, dan Janenan. Dari sekian banyak kesenian rakyat yang ada di desa Talunombo, kesenian Warok merupakan salah satu jenis kesenian rakyat yang paling berkembang dan sangat populer di daerah Wonosobo dibandingkan dengan kesenian rakyat yang lainnya. Hal tersebut terbukti dalam perkembangannya ditandai dengan banyaknya peminat yang ingin mementaskan pertunjukan Kesenian Warok, dibandingkan dengan kesenian lain yang ada di daerah tersebut (Agus, 20 Agustus 2016).

Kesenian Warok merupakan gabungan dari seni musik dan seni tari. Pemain kesenian Warok berjumlah sekitar 20 orang. Para pemain merupakan satu kesatuan, tidak terikat oleh tugas masing-masing, kadangkadang seorang pemain dapat bertugas sebagai penabuh gamelan atau sebagai penari dalam pementasan kesenian tersebut.

Tata rias dan properti yang digunakan pada Kesenian Warok memiliki kekhasan. Para penari menggunakan riasan hitam tebal pada wajah. Bagian alas kaki mengenakan gelang klinthingan sehingga menimbulkan suara riuh gemerincing tiap gerakannya. Hentakan kaki para penari dan musik gamelan yang berdentum membuat kemeriahan sebuah pentas Kesenian Warok. Para penari yang menggunakan riasan hitam tebal pada wajah, menari mengikuti irama musik gamelan yang mengiringi.
Dalam setiap pementasannya para penari warok selalu melibatkan hal gaib karena dalam setiap pementasannya selalu ada penari yang kesurupan. Selain itu banyak sekali sesajen yang disediakan untuk memenuhi permintaan para dhanyang yang merasuk kedalam tubuh penari. Keberadaan seni tradisi merupakan bagian yang tak terpisahkan dari kebudayaan masyarakat pendukungnya. Seni difungsikan sebagai salah satu sarana dilaksanakannya aktivitas budaya mereka. Terutama cabang seni tradisional di Jawa, baik langsung maupun tidak langsung hampir selalu berkaitan dengan upacara dan ritual keagamaan (Simuh dalam Soedarsono 1985: 64). Masyarakat sebagai pendukung kesenian mengalami berbagai perubahan sesuai dengan perkembangan jamannya. Keberadaan, peranan, fungsi, dan bentuknya akan bergeser atau berubah seiring dengan situasi dan kondisi masyarakat pendukungnya. Perkembangan dan perubahan yang terjadi pada Kesenian Warok terdapat pada unsur musikal, unsur urutan sajian, dan busana yang digunakan.

Peranan Kesenian Warok masih tampak dalam masyarakat Talunombo, meskipun sudah mengalami perkembangan dan perubahan, misalnya dalam acara bersih desa. Kenyataan ini menunjukkan bahwa peranan kesenian erat kaitannya dengan kehidupan masyarakat. Hal ini sesuai dengan pendapat Edi Sedyawati, melihat bahwa bermacammacam peranan masih dimiliki oleh kesenian dalam kehidupan, dan peranan itu ditentukan oleh keadaan masyarakat, maka besarlah arti kondisi masyarakat ini bagi pengembangan kesenian (Sedyawati, 1998:61). Sehubungan dengan peranan kesenian, terbukti Kesenian Warok sampai sekarang masih dipercaya 
masyarakat Desa Talunombo, karena kesenian masih digunakan dalam berbagai ritual dan acara daerah.

Ciri dan identitas sajian Kesenian Warok dapat divisualisasikan melalui tiga aspek, yakni: aspek musikal, ragam gerak, dan alur sajian. Jika seorang pelaku Kesenian Warok memiliki ragam gerak yang lain (berbeda) dari sajian Kesenian Warok secara umum, tetapi ragam gerak yang disajikan dapat diterima atau bahkan disukai oleh masyarakat pendukungnya, maka ragam gerak tersebut akan menjadi ciri khas dari Kesenian Warok. Demikian halnya alur sajian dan aspek musikal. Kesenian Warok akan dianggap mempunyai kekhasan jika mampu membawakan sajian yang berbeda dengan pertunjukan Kesenian Warok secara umum, ketika disajikan mendapat apresiasi positif dari masyarakat.

Mengulas tentang ciri dan identitas Kesenian Warok dilihat dari unsur-unsur sajiannya, peneliti tertarik untuk melakukan penelitian terhadap sajian Kesenian Warok yang ada di Desa Talunombo khususnya pada kelompok kesenian Projo Mukti. Kesenian Warok Projo Mukti yang ada di Desa Talunombo memiliki kekhasan atau keunikan tersendiri, sehingga masyarakat masih tertarik untuk mementaskannya. Selain itu, kelompok kesenian Projo Mukti mampu mengikuti perkembangan zaman dan selera masyarakat yaitu dengan menyajikan bentuk tari dan musik yang lebih modern, serta menambahkan beberapa alat musik untuk membantu memeriahkan setiap pertunjukan Kesenian Warok, namun tanpa menghilangkan ciri khas dari Kesenian Warok yang terdahulu. Hal tersebut dilakukan supaya pertunjukan Kesenian Warok tidak membosan-kan dan masyarakat memiliki antusias yang tinggi untuk menyaksikan Kesenian Warok.

Musik merupakan pendukung utama Kesenian Warok, sehingga dengan kehadiran musik menjadikan Kesenian Warok hidup dan ada rohnya. Sesuai dengan perkembangan zaman Kesenian Warok juga mengalami perkembangan yang cukup pesat. Hal ini ditandai dengan Kesenian Warok masuk panggung seni pertunjukan modern, sejalan dengan perkembangan keseluruhan unsur pertunjukannya sendiri.

Perkembangan selanjutnya mulai diadakannya festival, lomba yang mengikutsertakan Kesenian Warok. Hal ini membawa pengaruh yang cukup berarti bagi perkembangan Kesenian Warok beserta semua aspek-aspeknya. Salah satu dampak dari perkembangan ini adalah semakin maraknya musik-musik yang bukan musik Kesenian Warok, ikut masuk dan ditampilkan dalam pertunjukan Kesenian Warok. Kendatipun Kesenian Warok telah banyak dimasuki atau disisipi unsur-unsur musik lain seperti musik dangdut, campursari, regae, dan lainnya, namun kedudukan musik atau gending Kesenian Warok tetap mempunyai kedudukan tersendiri dalam suatu garap komposisi musiknya. Garap musik Kesenian Warok yang tradisi masih sangat eksis dan dipegang teguh oleh para seniman (musisi/pengrawit) Kesenian Warok.

Kesenian Warok memiliki beberapa ragam bentuk gending dan irama. Permasalahan musikal di dalamnya pun cukup kompleks, mulai dari masalah instrumentasi, pola-pola garap permainan instrumen seperti kendang, bendhe, senggakan, interaksi musikal, dan masalah musikalnya. Berbagai permasalahan musikal Kesenian Warok cukup menarik untuk diungkap, karena memiliki berbagai permasalahan musikal yang cukup kompleks.

Telah dijelaskan pada alenia sebelumnya, bahwa Kesenian Warok memiliki tiga aspek, yakni: aspek musikal, bentuk sajian, dan ragam gerak, namun dalam hal ini peneliti membahas pada musikalnya. Alasannya adalah bahwa dari ketiga aspek tersebut, yang sesuai dengan disiplin ilmu yang peneliti miliki adalah musikalnya. Musik atau gending di dalam pertunjukan Kesenian Warok memiliki peran yang cukup vital, sebagaimana dikemukakan oleh Rahayu Supanggah bahwa gending untuk keperluan tari memerlukan garap khusus pada beberapa unsurnya (Supanggah, 2007: 262).

Pemikiran di atas, menjadi latar belakang peneliti untuk melakukan penelitian terhadap kajian musikal dalam Kesenian 
Warok yang ada di Desa Talunombo, Kecamatan Sapuran, Kabupaten Wonosobo. Hal-hal yang berhubungan dengan ragam gerak dan alur sajian tidak dibahas secara detail, melainkan diinformasikan seperlunya untuk menjembatani peneliti melakukan identifikasi.

Atas dasar uraian yang telah dikemukakan di dalam latar belakang, maka berbagai masalah yang menarik untuk mendapatkan pemecahan dan jawabannya, dirumuskan dalam beberapa pertanyaan. 1) Bagaimana peran musik di dalam Kesenian Warok di Desa Talunombo Kecamatan Sapuran Kabupaten Wonosobo? 2) Bagaimana garap instrumen Kesenian Warok dimaksud?

\section{Pembahasan}

Kehadiran musik di dunia ini sangat mempengaruhi dan tidak lepas dari kehidupan manusia, bahkan musik seakan telah menyatu dalam kehidupan manusia. Musik merupakan nada atau suara yang disusun disertai bunyibunyian dari alat musik sehingga mengandung lagu, irama, dan kekompakan (Salim, 1991:1251). Tidak hanya dari alat musik namun berbagai bunyi dari mana saja dapat menjadi musik apabila terbentuknya musik tersebut terdapat elemen-elemen musik di dalamnya. Berdasarkan ensiklopedi Nasional Indonesia, musik dapat dikatakan interaksi tiga elemen, yaitu irama, melodi, dan harmoni.

... Irama adalah pengaturan suara dan waktu, panjang atau pendek. Irama membantu musik memberikan karakternya,... Semua musik mempunyai irama dan kecepatan musik yang disebut tempo. Kombinasi beberapa tinggi nada dan beberapa irama dapat menghasilkan sebuah melodi atau sebuah lagu. Beberapa bagian pendek hanya mempunyai satu melodi, sedangkan bagian yang lebih panjang mungkin terdiri atas beberapa melodi, berbeda yang memberikan kontras pada musik dan membuatnya bervariasi (Setiawan, 1990:413).
Keadaan diatas juga dapat tertuang pada fenomena alam seperti hujan, terkadang suara hujan yang tadinya deras tiba-tiba reda dan sesaat kemudian menjadi deras kembali. Keadaan yang demikian seperti halnya tempo dalam musik. Pada pertunjukan musik ada kalanya tempo musik harus dimainkan pelan atau cepat. Hal ini dalam musik karawitan Jawa disebut laya cepet (tempo cepat), laya sedeng (tempo sedang) dan laya cepet (tempo cepat).

Musik mempunyai dua fungsi yaitu mandiri dan digunakan untuk keperluan lain sebagai bagian dari sebuah pertunjukan, seperti tari, wayang, film/teater, fashion show, upacara dan lain sebagainya. Dalam dunia karawitan, oleh Trustho kedua peran tersebut dikatakan sebagai in action dan ex action. Peran in action dapat dilihat apabila karawitan itu sejalan dengan partnernya, sedangkan peran ex action apabila karawitan hanya berfungsi melatar belakangi (Trustho, 2005: 4).

Dalam fungsinya yang pertama bahwa musik dimainkan secara mandiri menuntut penikmat ataupun pendengar untuk lebih berkonsentrasi saat mendengarkan musik tersebut, sehingga akan menimbulkan kepuasan tersendiri bagi para penikmatnya. Hal ini bisa terjadi pada orkestra-orkestra yang dalam permainannya tanpa dikaitkan dengan keperluan lain seperti tari, wayang, teater dan lain sebagainya. Fungsinya yang kedua musik dijadikan sebagai pendukung dari sebuah pertunjukan. Tanpa adanya musik pertunjukan tidak akan dapat berjalan sebagaimana mestinya. Musik dapat digunakan untuk mengiringi saja, contoh untuk mengiringi upacara, selain itu musik juga dapat dipakai untuk membentuk suasana seperti yang terjadi pada drama atau film. Adegan yang tidak terlalu menegangkan akan menjadi mencekam saat musik ikut terlibat dalam pertunjukan tersebut. Dengan demikian musik dapat mendukung suasana dari pertunjukan, sehingga dapat mempengaruhi jiwa penikmatnya saat menyaksikan pertunjukan tersebut.

Melihat musik dapat ditempatkan di mana saja dan digunakan untuk kepentingan apa saja, maka musik bersifat luwes. 
Kenyataan tersebut tampak pada pertunjukan Kesenian Warok, musik digunakan untuk mengiringi tarian di setiap permainannya. Musik dalam Kesenian Warok cukup sederhana, bahkan orang awam mengatakan musik Kesenian Warok itu monoton. Pengulangan irama seakan banyak terjadi di setiap pertunjukannya. Hal ini Mathias Supriyanto menjelaskan bahwa karena pemberian iringan dengan tekanan yang ajeg pada semua bagian atau gerak bisa menimbulkan kesan monoton (Supriyanto, 2002: 55).

Keberadaan musik sangat menentukan jalannya pertunjukan, baik vokal maupun instrumen dapat dijadikan sebagai pengiring dari sebuah pertunjukan. Meskipun musik Kesenian Warok hanya sedikit menggunakan melodi vokal, namun irama yang terbentuk dapat mendukung pertunjukan. Peranan musik dalam pertunjukan Kesenian Warok dapat menciptakan suasana yang diperlukan dalam setiap tariannya. Penonton dapat dibuat takjub oleh berbagai gerak tarian yang disajikan oleh para penari Kesenian Warok, yang bertindak sebagai peran utama dalam pertunjukan, akan tetapi tarian akan berjalan dengan bagus apabila terdapat musik yang menyertainya.

Peran beberapa jenis instrumen musik pukul begitu berarti untuk membentuk sebuah musik Kesenian Warok. Meskipun musik yang dimainkan memiliki volume yang keras dan ramai, namun suara itulah yang diharapkan dalam musik Kesenian Warok. Alunan bunyi musik tersebut yang membantu para penari Warok untuk menampilkan setiap gerakannya. Kesenian Warok tidak jauh berbeda dengan kesenian-kesenian Indonesia yang banyak menggunakan alat musik perkusi dalam pertunjukannya. Meskipun sama-sama menggunakan alat musik perkusi namun jenis alat musik dan musiknya pun berbeda. Masing-masing kesenian mempunyai ciri khasnya sendiri-sendiri, yang memudahkan masyarakat cepat mengenalinya walaupun hanya dengan mendengar musik dari sebuah pertunjukan.

\section{Fungsi Musik dalam Berbagai Keperluan}

Kesenian Warok beserta musiknya telah menjadi salah satu bentuk budaya dan tradisi bagi masyarakat pendukung kesenian ini. Bentuk budaya dimaksud adalah digunakannya kesenian ini untuk sejumlah keperluan. Berikut fungsi dari aspek musik atau tabuhan Kesenian Warok.

\section{Fungsi Musikal}

Fungsi untuk seni pertunjukan tentunya mengarah juga pada sisi hiburan. Kesenian Warok sebagai kesenian rakyat, dipahami oleh masyarakat sebagai seni pertunjukan tari. Atas dasar ini, aspek musik Kesenian Warok dapat disebut sebagai musik tari, atau dengan kata lain berfungsi sebagai musik tari.

a. Musik Tari

Fungsi pokok musik Kesenian Warok adalah sebagai musik tari untuk Kesenian Warok. Sejak terbentuknya Kesenian Warok musik memang sudah digunakan untuk mengiringi tarian Warok, meskipun masih bersifat sederhana. Namun, tetap instrumen dan musik yang digunakan adalah instrumen musik Warok. Seiring perkembangan zaman musik Kesenian Warok terus berkembang, terlihat dari penambahan alat musik yang semakin beragam dan pola tabuhan yang semakin bertambah.

\section{b. Musik Mandiri (Tanpa Tari)}

Selain sebagai musik tari, musik Warok juga sering disajikan tidak dalam keperluan sebagai musik tari. Dalam pertunjukan Kesenian Warok pun sajian musik Warok tidak mesti ditujukan sebagai musik tari (tarian Warok). Beberapa kasus yang menunjukkan bahwa musik Kesenian Warok dapat berfungsi untuk keperluan bunyi-bunyian (tetabuhan) mandiri, tanpa bermaksud nabuhi suatu tarian (bukan sebagai musik tarian Warok). Hal ini bisa dilihat dari aktivitas-aktivitas seniman Kesenian Warok ketika melakukan latihan, seringkali ia nabuh musik tanpa sajian tari, dan cukup untuk dinikmati. Saat pentas pun, sebelum atau disela-sela sajian tarian Warok, penyajian tabuhan Warok tanpa tari sering disajikan, dan bukan sekedar mengisi waktu 
luang tetapi juga dinikmati/dihayati oleh para penonton. Menurut pengamatan, para penikmat Kesenian Warok pun tampak menikmati musik Warok.

Pada tahun 2000-an sekarang ini Kesenian Warok cukup inovatif dalam penggarapan musiknya. Seperti halnya dengan mengangkat lagu-lagu populer (terutama Jawa) seperti langgam, campursari, dangdut dan sejenisnya, yang telah masuk dapur rekaman komersial tanpa meninggalkan tabuhan asli Kesenian Warok. Kenyataan ini juga menunjukkan bahwa musik Warok kini bukan sekedar musik tari, namun juga berfungsi sebagai bunyi-bunyian yang dapat dinikmati oleh penikmatnya, meskipun tanpa adanya unsur tari dalam Kesenian Warok.

Dalam pembelajaran garap musik Kesenian Warok secara tradisional dilakukan melalui budaya lisan. Hal tersebut seperti dikatakan Taat bahwa dirinya dan banyak pemain musik Kesenian Warok pada zaman dahulu masih berlaku hingga sekarang, umumnya menimba kemampuan dengan cara ngèngèr, yaitu proses belajar tradisional, dimana para calon musisi selalu mengikuti aktivitas berkesenian dari gurunya. Dalam hal ini terjadi proses belajar mengajar dengan interaksi antara murid dan guru secara langsung. Penyampaian materi garap tabuhan oleh seorang guru kepada muridnya diberikan dengan memberikan contoh-contoh praktik. Para murid berusaha mendengarkan atau melihat dengan seksama praktik dari guru.

Selain belajar musik Kesenian Warok dengan cara ngèngèr, para musisi juga bisa belajar melalui mendengarkan sajian musisi lain ataupun rekaman kaset, apa yang dilihat dan didengarkan selanjutnya ditirukan. Dilihat dari cara belajar memang tampak adanya perbedaan antara bentuk belajar yang dilakukan antara musisi satu dengan yang lain. Tetapi secara sifat, proses transfer pengetahuan sebenarnya memiliki kesamaan. Keduanya tidak menggunakan metode notasi sebagai median transfer pengetahuan, melainkan hanya dengan cara mengamati praktik sajian sumber garapnya (guru). Pengamatan dilakukan dengan cara melihat dan mendengarkan. Informasi garap dari hasil pengamatan mereka simpan dalam memori ingatan (niteni). Memori ingatan inilah yang akan menjadi pijakan para musisi Kesenian Warok dalam menyajikan garap musik Kesenian Warok. Teknik belajar seperti ini selanjutnya lebih dikenal dengan istilah nguping atau kupingan.

\section{Fungsi Sosial}

Selain memiliki daya sugesti terhadap penghayat dan penikmatnya untuk melakukan gerakan-gerakan (joget), tabuhan dapat mengobarkan semangat dan keberanian pada diri pendengar dan penikmatnya. Inilah sebabnya, musik Warok pernah disertakan pada sebuah acara ritual untuk siswa suatu perguruan silat dan tenaga dalam di Wonosobo, untuk mengobarkan jiwa keberanian, kegagahan, dan maskulinitas para siswa perguruan silat dan tenaga dalam tersebut.

Fungsi musik Kesenian Warok untuk acara ritual dalam perguruan silat dan tenaga dalam tersebut dikaitkan dengan adegan tarian Warok yang mempresentasikan latihan kanuragan murid-murid Ki Ageng Surya ngalam pada masa lalu. Terlepas dari hubungannya dengan keperluan pertunjukan Kesenian Warok, musik Warok jelas-jelas digambarkan sebagai musik pengiring latihan kanuragan atau sejenisnya.

\section{Keterkaitan Musik dengan Warok.}

Pembicaraan awal telah dijelaskan bahwa berhasilnya sebuah pertunjukan bila didukung satu sama lain unsur-unsur yang terdapat didalamnya. Begitu pula dengan Kesenian Warok, pertunjukan Kesenian Warok akan dapat berjalan apabila didukung oleh beberapa unsur yang terkait seperti musik, gerak, properti, kostum, serta tempat. Unsurunsur tersebut dapat membantu pertunjukan. Selain itu unsur ruang dan waktu serta tenaga juga dibutuhkan dalam pertunjukan Kesenian Warok. Unsur ruang untuk pengekspresian emosional, waktu mengetengahkan sebuah urutan temporal yang diekspresikan melalui ritme. Dalam penyajiannya unsur waktu 
dituangkan melalui ritme, sehingga terbentuk irama tertentu, dan unsur tenaga berhubungan dengan pengaturan tensi tubuh (Trustho, 2005:55).

Penyatuan jiwa sangat diperlukan dalam memainkan Kesenian Warok. Tidak hanya pada musisi dengan musiknya saja, namun dalam beratraksipun juga membutuhkan penyatuan jiwa untuk menghasilkan sajian seperti yang diinginkan. Gerak penari warok menjadi hidup seperti layaknya karakter warok yang sesungguhnya apabila dalam memainkannya menggunakan penghayatan. Penari harus mengetahui gerak dan karakteristik seorang Warok, untuk mendapatkan hasil sajian yang elok dan memukau penonton. Cara seorang Warok berjalan, cara makan, melompat, menari, dan lain sebagainya. Karakter Warok disajikan semirip mungkin, untuk menunjang agar pementasan Kesenian Warok lebih menarik.

Gerak-geraknya yang khas seorang Warok mengundang banyak penonton untuk melihat dan menikmati pertunjukan Kesenian Warok. Ekspresi wajah juga sangat dibutuhkan untuk mendukung sajian pertunjukan, selain kelincahan geraknya. Melalui ekspresi wajah, pertunjukan Kesenian Warok terkesan lebih hidup. Tidak hanya ekspresi wajah para penari yang menggunakan kostum Warok, para penari yang menggunakan topeng juga harus lihai memainkan ekspresi mimik wajah sesuai dengan peran yang sedang disajikan.

Kesenian Warok mempunyai dua macam topeng, berbeda dengan topeng yang biasa digunakan tari topeng pada umumnya. Dalam pertunjukan Kesenian Warok, topeng tersambung kain panjang yang fungsinya untuk menutupi badan pemain depan dan belakang. Kedua tangan pemain digerakgerakkan ketika ia hendak memainkan ekspresi wajah seperti binatang aslinya.

Sebagaimana telah dijelaskan diawal bahwa musik pada Kesenian Warok adalah sebagai salah satu peran penting jalannya sebuah sajian. Alunan musik yang begitu ramai akan membawa ungkapan ekspresi dari penari Warok untuk disampaikan kepada penonton. Munculnya ekspresi disebabkan adanya perpaduan unsur musik dan gerak. Penuangan musik dan gerak yang disajikan dalam pertunjukan Kesenian Warok biasa dilakukan melalui komunikasi antara kedua belah pihak. Menurut Thrustho komunikasi tersebut disebut dengan komunikasi non verbal, yaitu dengan isyarat berupa pola-pola yang dimiliki oleh keduanya, baik gerak maupun musik. Antara pola musik dengan gerak akan membentuk sebuah interaksi. Dan pertemuan keduanya (musik dengan gerak) tersebut dapat ditangkap oleh manusia dan di interpretasikan sebagai sebuah simbol.

Kesan dapat terbentuk tidak hanya dari kostum, tata rias atau gerak saja, namun bunyi instrumen pun dapat menciptakan kesan dari sebuah pertunjukan. Seperti halnya dalam pertunjukan Kesenian Warok yang hanya mempunyai beberapa pola musik saja, namun bunyi dari beberapa pola musik tersebut mempunyai kesan yang dapat memperkuat karakter Warok. Munculnya bunyi dari beberapa instrumen dan dibentuk dalam beberapa pola tersebut seakan dapat mempengaruhi jiwa manusia yang mendengarnya. Hal ini seperti pendapat Aristoteles seorang filsuf Yunani pada abad IV sebelum Masehi, yang dituliskan oleh Grout dalam A History of Western Music, dan Judith Becker tertulis dalam buku yang berjudul Kalau Bahasa Dapat Diterjemahkan.

Secara langsung musik menirukan gejolak dan keadaan jiwa - kelembutan, kemarahan, keberanian, keikhlasan hati, dan sebagainya. ...Oleh karena itu, apabila seseorang mendengarkan musik yang menirukan gejolak jiwa tertentu, ia akan masuk ke dalam gejolak jiwa yang sama; dan jika di dalam jangka waktu yang lama dan terus menerus ia terbiasa mendengarkan jenis musik yang membangkitkan gejolak jiwa yang rendah dan murahan, maka pada dirinya akan terbentuk watak yang sama pula. (Grout, 1975: 7-8, Judith Becker, 1990: 19-20).

Bunyi dari sebuah instrumen dapat mempengaruhi jiwa, tidak selalu bunyi musik 
yang dimainkan secara berasama atau orkestra. Dalam musik Kesenian Warok, suara kendang yang tegas sangat mendukung pertunjukan. Hal ini dikarenakan kesan gagah, wibawa yang ditimbulkan dari suara kendang. Dengan demikian warna suara tersebut dapat memperkuat karakter Warok menjadi lebih hidup. Kendang dapat bertempo cepat dan dapat pula bertempo lambat, meskipun tempo kendang dimainkan lambat namun kesan gagah masih tampak dalam warna suara tersebut.

\section{Keterkaitan Musik dan Ndadi ( Warok)}

Musik dan kebudayaan memiliki hubungan yang saling mempengaruhi, karena musik ataupun kebudayaan berkembang seiring dengan peradapan manusia. Berbagai kebudayaan diberbagai penjuru dunia tidak terpisah dari penggunaan musik. Musik pada awalnya hanya dianggap sebagai bunyi atau suara, namun kini anggapan mengenai musik tidak lagi demikian. Dello Joio, seorang komponis asal Amerika mengatakan "mengenal musik akan menumbuhkan rasa penghargaan akan nilai seni, selain menyadari akan dimensi lain dari kekayaan yang selama ini tersembunyi". Penganut agama nasrani menggunakan musik sebagai sarana peribadatan, demikian juga agama Hindu dan Budha menempatkan musik untuk mencapai penyatuan dengan dewa-dewa mereka. Bagi umat Islam khususnya Jawa, musik juga memiliki tempat tersendiri yakni sebagai syiar/ dakwah.

Kesenian Warok hidup di tengah lingkungan yang pendukungnya beragama Islam, maka pembicaraan mengenai Kesenian Warok lebih banyak menggunakan sudut pandang Islam. Umat Islam di Persia, terutama penganut aliran tasawuf menggunakan musik sebagai media untuk mendapatkan pengalaman kerohanian dan meningkatkan penghayatan religius. Penghayatan yang tinggi di kalangan tasawuf mampu mencapai tingkat peleburan dan kekekalan dengan Yang Maha Kuasa. Musik dikalangan sufisme ini hanya satu contoh kekuatan musik dan kemampuan musik yang mampu mempengaruhi keadaan seseorang. Seperti pernyataan Mary Bassano yang dikutip Darmo Budhi Suseno dalam "Gong" (No.56/VI/2004).

Bunyi-bunyian dan nada tertentu dapat mengubah sifat kimiawi tubuh kita, dan dapat menaikkan emosi yang rendah menjadi keadaan kesadaran yang baru, yang dengan cara ini dapat menyelaraskan instrumennya, yakni tak lain adalah diri kita sendiri".

Kesenian Warok hidup ditengah budaya Jawa yang masyarakatnya menganut kepercayan kejawèn. Dalam kerangka pikir kejawèn, rasionalitas selalu digabungkan dengan intuisi, kepercayaan Islam dicampur dengan Hindu dan Animistik. "Orang Jawa selalu berfikir secara induktif, manganalisis pengalaman dan peristiwa sambil meraih esensinya (rasa-nya, kebenaran dibalik sebuah fenomena) secara intuitif dengan cara langsung tanpa konstruksi teoritis dan riset yang membosankan" (Nick Mulder, 2001: 138). Mungkin hal ini yang mendasari, satu anggapan bahwa proses ndadi dalam Kesenian Warok berkaitan dengan pola-pola musikal lagu Kesenian Warok dan berhubungan dengan makhluk gaib.

Ndadi adalah sebuah peristiwa ketika seorang penari Warok mengalami tingkat kesadaran tertentu, sehingga tidak dapat mengendalikan raganya. Masyarakat Talunombo menganggap peristiwa ini sebagai "kesurupan". Kesurupan adalah suatu kondisi ketika raga seseorang dirasuki oleh makhluk gaib yang disebut dhanyang. Kepercayaan masyarakat Talunombo kepada dunia gaib dan kepada hubungan dengan orang-orang yang sudah meninggal, merupakan sifat-sifat kebudayaan petani ladang yang sampai saat ini masih dipertahankan. Realitas ini memberikan kesadaran bahwa nilai-nilai lokal tidak dapat dipisahkan dalam penciptaan keseniannya. Memahami kesenian Jawa tidak dapat melupakan sistem kepercayaan asli masyarakatnya. Budaya masyarakat Indonesia lama adalah budaya religius, budaya mitos, budaya spiritual, berbeda dengan orang modern yang lebih profan, rasional-obyektif (Jakob Sumardjo, 2004: 33). Hal terpenting dari wacana ini adalah adanya 
kepercayaan terhadap sesuatu yang transenden, dan upaya menghadirkan yang transenden tersebut.

Awalnya kemunculan Kesenian Warok mungkin tidak diketahui secara pasti. Kepercayaan masyarakat Talunombo terhadap makhluk gaib menunjukkan bahwa kebudayaan primitif masih berpengaruh dalam masyarakat Talunombo. Menurut Jakob Sumardjo (2004: 33), pada masa primitif tingkat kebudayaan manusia masih sangat sederhana dan sangat percaya terhadap kekuatan makhluk gaib. Masa primitif memandang dunia ini sebagai kosmosentris dan biosentris. Kesatuan alam roh, alam semesta dan alam manusia amat nyata dalam pandangan religius mereka. Ketiga hal tersebut disatukan oleh kekuatan adikodrati: hidup ini dikelilingi gaya-gaya gaib dan persoalannya kemudian adalah bagaimana manusia dapat memenejnya. Kebudayaan mereka adalah persoalan manajeman daya-daya adikodrati yang terdapat di mana-mana itu. Masyarakat Talunombo sampai saat ini juga masih mempercayai dan menggunakan praktekpraktek mistik. Kesenian Warok dan fenomena ndadi menjadi salah satu contoh kepercayaan masyarakat Talunombo terhadap makhluk gaib.

Kesenian Warok menjadi contoh bagaimana masyarakat mengelola daya adikodrati. Unsur-unsur yang ada dalam jenis tari ini memiliki bentuk yang belum diolah secara koreografis seperti halnya pola gerakannya, iringan musik, pakaian, dan riasannya pada umumnya masih sederhana (Soedarsono, 1977: 18). Masyarakat percaya bahwa makhluk gaib membutuhkan media untuk menunjukkan eksistensi mereka. Penari ndadi dijadikan media makhluk gaib, kemudian dimanfaatkan sebagai hiburan.

Bagi masyarakat Talunombo fenomena ndadi selalu dikaitkan dengan musik. Melihat komposisi musik Kesenian Warok dengan pola yang diulang-ulang, sehingga tidak sulit untuk belajar musik Kesenian Warok, karena tidak ada aturan baku. Tetapi bagaimana musik yang sederhana mampu mempengaruhi kesadaran seseorang. "Nada naik dan turun, intensitas serta aksen dan temponya bisa menjadi iringan tari, dan menimbulkan ekspresi emosional" (Margareth N. H Doubler, 1959: 122). Musik sebagai perangsang seorang penari mengalami ndadi, juga harus didukung dengan situasi dan kondisi pertunjukan. Pada saat latihan, meskipun musik iringan ndadi desajikan tetapi tidak terjadi peristiwa ndadi. Hal ini terjadi karena emosi dari penari itu sendiri tidak muncul, karena biasanya yang menonton adalah rekan-rekan mereka sendiri. Musik dalam proses ndadi adalah media yang membantu seseorang meningkatkan emosi yang kemudian direspon oleh tubuh.

Pola tabuhan iringan Kesenian Warok yang ritmik, menimbulkan perasaan untuk terus bergerak. Ketika iringan menyajikan lagu dengan tempo cepat, dengan kondisi fisik penari yang lelah sangat mudah untuk dirasuki oleh makhluk gaib. "musik juga dapat berakibat pada tekanan darah, mempercepat pulsa, sirkulasi, aktifitas gelombang otak, metabolisme dan respon fisik, serta emosi yang tak terhitung jumlahnya" (Djohan, 2003: 223). Pernyatan ini menunjukkan bahwa musik dapat mempengaruhi keadaan seseorang.

Musik dalam tarian bukan hanya sebagai iringan, tetapi musik adalah faktor pendukung tari yang tidak dapat ditinggalkan. Musik dalam Kesenian Warok menjadi sangat penting ketika masyarakat manganggap bahwa suaranya mampu menyebabkan seseorang mengalami trance. Musik menjadi unsur yang memperkuat tekanan pada gerak tari dan sebagai pendukung suasana pertunjukan. Seorang ahli tari Jawa, Pangeran Suryadiningrat memberikan pengertian tentang tari sebagai berikut, "Tari adalah gerak dari seluruh anggota tubuh manusia yang disusun selaras dengan irama musik serta mempunyai maksud tertentu" (Soedarsono, 1992: 81).

\section{Sarana Musikal}

Unsur-unsur musik dapat diidentifikasi dalam garap Kesenian Warok diantaranya adalah: instrumen, laras, irama atau tempo, ritme, dan volume. 


\section{Instrumen}

Banyak kesenian tradisi Nusantara yang menggunakan perangkat alat musik atau ansambel yang disebut gamelan. Pengertian “...alat musik pukul atau perkusi..." cukup memberi penjelasan tentang definisi 'gamelan' secara umum. Kata gamelan berasal dari kata dasar gamel(bahasa Jawa), kata kerja nggamel, yang artinya memukul, menabuh. Istilah gamel, nggamel, atau gamelan memiliki makna yang dekat dengan istilah tabuh, nabuh, atau tabuhan. Berikut instrumen gamelan yang digunakan Kesenian Warok adalah:

a. Kendang

Kendang adalah instrumen dalam klasifikasi membranofon yang memiliki dua muka. (Pono Bonoe, 1984: 123). Kendang yang digunakan pada Kesenian Warok terdiri dari tiga buah, kendang besar, kendang tanggung menyerupai kendang ciblon, serta sebuah ketipung yang mirip dengan ketipung jaipong, posisi telungkup dan hanya bagian membran ukuran kecil saja yang dimainkan. Peran dari permainan kendang pada Kesenian Warok tidak jauh berbeda dengan peran kendang pada perangkat gamelan ageng, yakni berperan sebagai pemurba irama.

\section{b. Demung}

Demung adalah salah satu instrumen gamelan ageng termasuk dalam keluarga balungan. Demung berbentuk bilah yang terbuat dari perunggu atau kuningan, menghasilkan nada dengan oktaf terendah dalam keluarga balungan, dengan memiliki ukuran fisik yang lebih besar. Kesenian Warok di desa Talunombo hanya menggunakan demung berlaras pelog, ricikan ini terdiri dari tujuh bilah dengan urutan nada sebagai berikut:

$$
\begin{array}{lllllll||}
1 & 2 & 3 & 4 & 5 & 6 & 7
\end{array}
$$

Cara memainkannya dengan cara dipukul mengunakan tabuh yang biasanya terbuat dari kayu dengan bentuk seperti palu. Demung ditabuh sesuai dengan nada yang telah dirangkai menjadi sebuah lagu atau gending. Cepat lambat dan keras lemahnya tabuhan tergantung pada komando dari kendang. c. Saron

Saron memiliki bentuk yang sama dengan demung, hanya saja ukuran bilahnya lebih kecil. Selain itu jumlah bilah pada ricikan saron juga berbeda dengan ricikan demung. Saron yang digunakan dalam Kesenian Warok di desa Talunombo yaitu saron sanga yang mempunyai sembilan wilahan atau bilah bernada pelog dengan urutan nada sebagai berikut:

$$
\left\|\begin{array}{lllllllll}
6 & 1 & 2 & 3 & 4 & 5 & 6 & 7 & i
\end{array}\right\|
$$

Saron menghasilkan nada satu oktaf lebih tinggi daripada demung. Cara memainkannya juga sama dengan demung bisa saja sesuai dengan nada, atau bisa juga dimainkan dengan cara imbal dan nyacah ${ }^{2}$. Selain itu, dalam Kesenian Warok saron juga bisa dimainkan seperti instrumen saron penerus. Hal ini bertujuan agar tabuhan yang dihasilkan terasa lebih ramai.

\section{d. Kempul kecil (bendhé)}

Dalam karawitan Jawa kempul merupakan salah satu perangkat gamelan yang ditabuh, biasanya digantung menjadi satu perangkat dengan gong. Kempul atau bendhé ini merupakan instrumen yang paling tua dalam Kesenian Warok, karena sebelum ditambahkan beberapa intrumen lain seperti demung dan saron, dahulu Kesenian Warok hanya menggunakan dua kempul kecil, yang dimainkan bersama dengan kendang. Berdasarkan fungsinya, kempul atau bendhé dapat dikelompokkan sebagai ricikan struktural, yakni ricikan yang menegaskan sèlèh-sèlèh berat dari alur lagu dari gending yang disajikan.

\section{e. Drum dan Jidor}

Drum dan jidor merupakan instrumen pendukung dalam Kesenian Warok. Instrumen ini bertugas untuk memeriahkan tabuhan dari instrumen lainnya. Meskipun musik masih bisa mengiringi tarian Warok tanpa menggunakan instrumen ini, namun pertunjukan yang dihasilkan tentu akan kurang maksimal, karena instrumen ini dapat memperkuat karakter dari setiap gerak penari Warok. 


\section{f. Vokal}

Unsur vokal dalam Kesenian Warok mempunyai kedudukan yang sangat penting. Unsur vokal ini disebut senggakan (senggak). Akan terasa hambar jika tabuhan musik Kesenian Warok tidak disenggaki (diberi vokal berupa senggakan). Melihat bentuknya, senggak merupakan manusia, namun dilihat dari pola musikal senggakan itu sendiri, erat kaitannya dengan tabuhan instrumen gamelan, maka disejajarkan dengan alat musik pada instrumentasi Kesenian Warok yang lain.

Para penyenggak selain menyajikan senggakan, biasanya juga alok, nggerok, atau nggereng, serta juga menyajikan lelagon. Dengan demikian, sebutan senggak oleh masyarakat Talunombo mencakup keseluruhan pelaku vokal Warok. Bentukbentuk vokal (senggak) dalam musik Kesenian Warok sendiri apabila dirinci terdiri sebagai berikut.

\section{1) Senggakan}

Senggakan berasal dari kata senggak mendapat akhiran an. Senggak memiliki arti bersuara santak, giyak, sorak, semangat. Dengan demikian dapat ditarik suatu pemahaman bahwa senggakan adalah bersuara santak sebagai bentuk interaksi musikal dalam pertunjukan karawitan, yang disajikan secara kelompok dan berlagu. Dengan kata lain senggakan adalah lagu vokal bersama di luar lagu pokok dengan serangkaian kata-kata indah (Suyoto, 2016: 137).

Senggak atau senggakan dalam Kesenian Warok mengacu pada pola tarian dan/atau kendangan. Pada tabuhan Kesenian Warok yang bukan dalam rangka sebagai musik tari, misalnya murni untuk tabuhan saja atau untuk menyajikan tembang, pola dan ritme senggakan juga mengacu pada pola kendhangan.

\section{2) Alok, Gerok}

Di dalam karawitan, alok adalah vokal bersama tidak bernada, dan kata-kata yang digunakan tidak memiliki arti (Suyoto, 2016:140). Alok-gerok yang penulis maksud adalah unsur vokal berupa suara manusia dengan warna dan karakter tertentu, diantaranya: teriakan (gerokan), erangan (gerengan), ungkapan bunyi atau suara tertentu, yang tidak ritmis atau tidak terikat irama namun disuarakan pada tempat-tempat tertentu, kaitannya dengan gerak dan suasana tari yang didukung oleh pola musik (tabuhan) tertentu.

3) Lagu

Penyajian vokal terutama yang berbentuk lagu dengan wadah tabuhan (musik) Kesenian Warok menjadi sesuatu yang dibanggakan bagi para seniman atau penikmat Kesenian Warok. Penyajian lagu-lagu yang mengambil repertoar dari langgam, lelagon dolanan Jawa, atau bahkan dari musik-musik populer atau dangdut. Penyajian semacam itu biasanya dilakukan bukan dalam rangka keperluan tarian Warok, akan tetapi lebih kepada penyajian bebas, selingan di sela-sela penyajian tarian-tarian, atau disajikan ketika para penari sudah mulai memasuki fase $n d a d i$ (kondisi dimana para penari kehilangan kesadaran diri karena dikuasai atau dirasuki oleh mahkluk gaib).

\section{Garap gending}

Penggarapan gending dengan melakukan inovasi dengan cara mengolah, menyegarkan dan mengemas bentuk sajian menjadi lebih menarik. selera masyarakat yang selalu berubah seiring dengan perkembangan jaman dan pengaruh dari kesenian bentuk lain, kemudian mengalihkan identitas sajian kesenian Warok di masyarakat menjadi semakin memudar dengan memasuki bentukbentuk baru seperti dangdut dan campursari.

Sebagai upaya untuk mengimbangi selera masyarakat, kelompok kesenian Warok di desa Talunombo mencoba mengembangkan garap gending kesenian Warok dengan inovasi serta disegarkan kembali kedalam bentuk kemasan yang baru. Inovasi yang dilakukan adalah dengan mengolah sajian lebih menarik, merubah bentuk gending dengan pola-pola yang lebih rapi dan dinamis tanpa harus keluar dari identitas (ciri khas) kesenian Warok.

Garap gending kesenian Warok dibagi dalam tiga bagian, yaitu bagian pertama garap gending untuk penari putri, bagian ke dua garap gending untuk penari putra, bagian ke tiga garap gending untuk penari putra dan 
putri masing-masing bagian dianalisis sebagai berikut:

\section{Garap Gending untuk Penari Putri}

Bagian pertama menggunakan gending bentuk srepeg laras pélog pathet nem, disajikan tanpa ngelik.

Notasi balungan: Srepeg laras pélog pathet nem

$$
\begin{array}{llll}
.6 .5 & .6 .5 & .2 .3 & .5 .3 \\
.5 .3 & .5 .3 & .5 .2 & .3 .5 \\
.7 .6 & .5 .3 & .6 .5 & .3 .2 \\
.3 .2 & .3 .2 & .3 .5 & .6 .5
\end{array} \|
$$

\section{Garap Gending Penari Putra}

Garap gending untuk penari putra terdiri dari beberapa bagian seperti berikut:

1. Notasi Balungan

Bagian Pertama

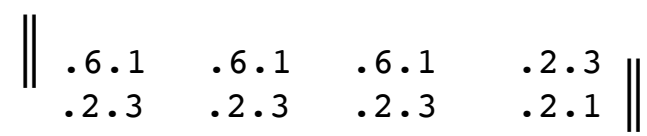

Bagian Kedua

$\left\|\begin{array}{llll}2321 & 2321 & 2321 & 2356 \\ 5356 & 5356 & 5356 & 5321\end{array}\right\|$

\section{Garap Gending untuk Penari Putra dan Putri}

Garap gending pada bagian putra dan putri ini menggunakan notasi balungan yang sama dengan notasi balungan garap sebalumnya. tabuhan kendang tentunya memiliki perbedaan karena harus menyesuaikan pola gerak tari oleh para pemeran warok. Berikut tabuhan kendang pada garap kesenian warok bagian putra dan putri.

\section{Garap Irama dan Tempo}

Salah satu unsur garap yang sangat mendasar dalam sajian gending dalam Kesenian Warok adalah irama. Dituturkan Supanggah, irama merupakan konsep menyangkut dengan ruang dan waktu. Berkaitan dengan ruang, irama merupakan bentuk panjang-pendek, lebar-sempit, banyaknya volume ruang untuk ditempati isian permainan musik, misalnya irama lancar, irama tanggung, irama dadi, dan sebagainya. Berkaitan dengan waktu, yakni kecepatan irama musik. Ada macam-macam tempo atau kecepatan irama, diantaranya: seseg (cepat), sedheng (sedang), tamban (lambat) (Supanggah, 2002:124).

Dalam Kesenian Warok dikenal tiga irama, yaitu irama I, irama II, irama III. Irama I dalam Kesenian Warok sejajar degan irama lancar pada gending gaya Surakarta, dan irama II pada Kesenian Warok sejajar dengan irama tanggung pada gending gaya Surakarta, sedangkan irama III jarang sekali digunakan karena pada sajian irama III lebih sering digunakan untuk klenèngan yang bersifat matmatan. Dalam sajian Kesenian Warok hanya menggunakan irama I dan II, untuk mempermudah pembicaraan selanjutnya dalam garap Kesenian Warok maka istilah yang digunakan adalah irama I (satu) untuk menyebut irama lancar dan irama II (dua) untuk menyebut irama dadi.

\section{Ritme}

Miller menyatakan bahwa ritme dihasilkan oleh faktor aksen (penekanan atas sebuah nada yang membuatnya berbunyi lebih keras) serta faktor durasi yang berkaitan dengan variasi panjang-pendek nada. Selanjutnya menurut Miller memiliki bermacam-macam karakter seperti: kuat lemah, teratur - tidak teratur, dan sederhana - rumit (2001:30-31). Dalam musikalitas Kesenian Warok unsur-unsur ritmik nampak pada permainan instrumen kendang, bendhé, hingga suara vokal senggak.

Tentu saja unsur ritme ini juga berkaitan dengan tarian yang ditampilkan. Banyaknya suasana dan karakter yang dipresentasikan sepeti: gagah, sigrak, gecul (lucu), dan garang, yang implementasinya tentu tampak juga pada tabuhan-nya. Hal ini untuk menciptakan dinamika tarian,yang turut didukung sepenuhnya oleh aspek musikal.

\section{Volume}

Musik Kesenian Warok menggunakan medium gamelan. Sering kali terjadi 
permainan musik yang menuntut adanya tabuhan (dalam arti pukulan) yang kadang keras, lirih, atau sedang. Sebagai contoh pada adegan tari yang energik, volume tabuhan gamelan harus keras supaya mendukung suasana menjadi semangat.

Selain penerapan variasi volume pada keseluruhan permainan gamelan, volume juga menjadi hal yang sangat diperhitungkan dalam memainkan tiap-tiap instrumen. Sebagai contoh adalah permainan demung dalam Kesenian Warok yang di dalamnya jelas-jelas memperhitungkan volume pukulan. Dalam permainannya selalu ada bunyi yang keras dan bunyi yang lirih serta bunyi yang sedang pada bagian-bagian tertentu. Perbedaan ketiganya (volume keras - lirih sedang) sangat jelas terdengar.

\section{Kesimpulan}

Kesenian Warok merupakan gabungan dari seni tari dan seni musik. Tema cerita menggambarkan kehidupan sesorang warok, sosok yang kuat, sakti dengan ciri khas mengenakan tali panjang dan besar (kolor warok) sebagai senjata andalan. Kesenian Warok terdapat beberapa penari bertopeng besar berwajah seram, menggambarkan sosok makhluk jahat menjadi musuh warok.

Secara turun-temurun sampai beberapa generasi, kesenian Warok masih tetap eksis sampai sekarang. Hal tersebut tidak lepas dari para pemain yang terus menerus, inovatif, namun tidak meninggalkan tradisi leluhur terdahulu yang tetap melibatkan makhluk ghaib dalam setiap pementasannya, dan selalu menyiapkan sesajen demi keberlangsungan pementasan.

Musik kesenian Warok, keberadaannya sangat menentukan jalannya pertunjukan. Peran musik kesenian Warok sangat dominan, untuk menciptakan suasana yang diperlukan. Kesan dapat terbentuk tidak hanya dari kostum, tata rias, atau gerak saja, namun bunyi instrumen pun dapat menciptakan kesan dari sebuah pertunjukan. Bunyi dari beberapa pola tabuhan mempunyai kesan yang dapat memperkuat karakter warok. Instrumen yang digunakan dalam tiap penyajiannya yaitu kendang, demung, saron, drumset, jidor, bendhé dan vokal. Selain itu, proses ndadi dalam kesenian Warok dipercaya berkaitan dengan pola-pola tabuhan yang mendukungnya. Musik menjadi media seseorang meningkatkan emosi yang kemudian direspon oleh tubuh. Pola tabuhan yang ritmik, menimbulkan perasaan untuk terus bergerak. Ketika musik dalam tempo cepat, dengan kondisi fisik penari yang lelah sangat mudah untuk dirasuki oleh makhluk gaib. Hal tersebut menunjukkan bahwa musik dapat mempengaruhi keadaan seseorang.

Kesenian Warok dalam setiap pementasannya melibatkan makhluk gaib. Masyarakat desa Talunombo masih mempercayai dunia gaib, hubungan roh dengan orang-orang yang sudah meninggal. Kepercayaan masyarakat Talunombo terhadap makhluk gaib menunjukkan bahwa kebudayaan primitif masih berpengaruh dalam masyarakat Talunombo. Kehidupan orang primitif tingkat kebudayaan manusia sangat sederhana dan kepercayaan terhadap kekuatan makhluk gaib sangat kuat. Masyarakat Talunombo sampai saat ini masih mempercayai dan menggunakan praktikpraktik mistik, masih percaya bahwa makhluk gaib membutuhkan media untuk menunjukkan eksistensinya. Penari warok yang ndadi dijadikan media makhluk gaib, kemudian dimanfaatkan sebagai hiburan. Kesenian Warok dan fenomena ndadi menjadi salah satu contoh kepercayaan masyarakat Talunombo terhadap makhluk gaib.

Pada dasarnya pertunjukan kesenian Warok sangat sederhana, namun para generasi muda mampu melakukan inovasi dengan cara mengolah, menyegarkan, dan mengemas bentuk sajian menjadi lebih menarik. Hal tersebut dilakukan sebagai upaya untuk mengimbangi selera masyarakat yang selalu berubah-ubah seiring dengan perkembangan jaman, mengolah sajian menjadi lebih menarik.

\section{(Endnotes)}

${ }^{1}$ Imbal: tabuhan/pukulan instrumen secara bergantian. 
${ }^{2}$ nyacah: tabuhan/pukulan instrumen yang diperbanyak atau dilipatkan.

\section{Kepustakaan}

Becker, Judith. 1990. Kalau Bahasa dapat Diterjemahkan, Mengapa Musik Tidak?, dalam Jurnal Masyarakat Musikologi Indonesia, Seni Pertunjukan Indonesia Th. 1 No.1.

Handayani, Umi. 1998. “Keberadaan dan Bentuk Pertunjukan Reog 'Singa Krida Muda Wacana' Dusun Widan Kelurahan Makam Haji Kartasura Kabupaten Sukoharjo". Skripsi. Institut Seni Indonesia Surakarta.

Kayam, Umar. 1981. Seni Tradisi Masyarakat. Jakarta: Sinar Harapan.

Kumorohadi. 2004. "Reog Obyogan: Keberlanjutan dan Perubahan Cara Penyajian dalam Pertunjukan Reog Ponorogo". Skripsi. Institut Seni Indonesia Surakarta.

Manggala, Bondan Aji. 2006. “Membangun Atraksi Ndadi Warok Komunitas Reog Singo Tamtomo Dukuh Prayan Desa Planggu Kecamatan Trucuk Klaten". Skripsi. Institut Seni Indonesia Surakarta.

Mulder, Nick. 2001. Ruang Batin Masyarakat Indonesia. Yogyakarta: Lkis.

Santosa, Ajid Heri. 2007. "Fungsi Slompret dalam Pertunjukan Reog Ponorogo". Skripsi. Institut Seni Indonesia Surakarta.

Sedyawati, Edi. 1981. Pertumbuhan Seni Pertunjukan. Jakarta: Sinar Harapan.

Soedarsono, R.M. 1999. Seni Pertunjukan Indonesia di Era Globalisasi. Jakarta: Direktorat Jendral Pendidikan Tinggi, Departemen Pendidikan dan Kebudayaan.
Supanggah, Rahayu. 2007. Bothekan Karawitan II: Garap. Surakarta: ISI Press.

Bothèkan Karawitan I. 2002. Jakarta: Masyarakat Seni Pertunjukan Indonesia,.

Suseno, Darmo Budi. 2004. Musik dan Dunia Sufisme, dalam Gong.

Suyoto. 2016. “Carem: Puncak Kualitas Bawa dalam Karawitan Gaya Surakarta". Disertasi. Program Studi S3 Pengkajian Seni Pertunjukan dan Seni Rupa.

Trustho. 2005. Kendang dalam Tradisi Tari Jawa. Surakarta: STSI Press.

\section{Daftar Narasumber}

1. Arifin, 28 tahun, pengendang pengganti sekaligus penari, asal Talunombo, Sapuran, Wonosobo.

2. Burhani, 80 tahun, pawang sekaligus tokoh yang mengerti banyak tentang kesenian Warok, asal Talunombo, Sapuran, Wonosobo.

3. Fahron, 25 tahun, pemusik sekaligus penggarap lagu kesenian Warok, asal Talunombo, Sapuran, Wonosobo.

4. Hartanto, 48 tahun, pawang yang menangani saat para penari warok mengalami ndadi, asal Talunombo, Sapuran, Wonosobo.

5. Sigit, 35 tahun, pengelola organisasi dalam kelompok kesenian Warok, asal Talunombo, Sapuran, Wonosobo.

6. Taat, 50 tahun, pengendang sekaligus pelatih kendang kesenian Warok, asal Talunombo, Sapuran, Wonosobo.

7. Wahyu, 28 tahun, sebagai pelatih sekaligus penari warok, asal Talunombo, Sapuran, Wonosobo. 